\title{
An investigation on how to estimate future cash flows: Evidence from Tehran Stock Exchange
}

\author{
Roghayeh Ahmdi Panah Banad Koki ${ }^{\mathrm{a}^{*}}$ and Iman Jokar ${ }^{\mathrm{b}}$
}

${ }^{a}$ Department of Accounting, Science \& Research Branch, Islamic Azad University, Fars, Iran ${ }^{b}$ Department of Accounting, Science \& Research Branch, Islamic Azad University, Fars, Iran

\section{H R O N I C L E}

\begin{tabular}{l}
\hline Article history: \\
Received October 28, 2013 \\
Received in revised format \\
25 November 2013 \\
Accepted 15 January 2014 \\
Available online \\
January 172014 \\
\hline Keywords: \\
Discretionary Accruals \\
Tehran Stock Exchange \\
Future Cash flow \\
\hline
\end{tabular}

\section{A B S T R A C T}

\section{Introduction}

One of the primary concerns on investment strategies is to study the quality of earnings and methods for predicting the future cash flow and there are several studies associated with this issue (Collins \& Hribar, 2000; Doyle et al., 2003; Francis et al., 2005; Hribar \& Craig Nichols, 2007). Dechow and Dichev (2002) recommended a new method for measuring the quality of working capital accruals and earnings. Accruals is able to shift or to adjust the recognition of cash flows over time so that the adjusted earnings could provide better prediction on firm performance. They argued that the quality of accruals and earnings is decreasing in the magnitude of estimation error in accruals and derived an empirical measure of accrual quality as the residuals from firm-specific regressions of changes in working capital on past, present, and future operating cash flows. Nam et al. (2012) reinvestigated the effect of the cash and accrual components of accounting earnings in forecasting future cash flows using out-of-sample predictions and market value of equity as a proxy for all possible future cash flows. They reported that, on average, accruals could improve upon current cash flow from operations (CFO) in forecasting future cash flows. In the cross-section, accruals' contribution was positively 
related to proxies for quality of accruals and governance. They also investigated the implications of accruals' predictive value for accrual-based market anomalies and reported that portfolios formed on stock return forecast using information from current CFO and accruals could result substantially positive returns on average, as opposed to CFO alone. They also reported that Sloan's accrual anomaly was associated to their accrual contribution anomaly. In fact, when accruals' contribution to future cash flow prediction was the highest, the accrual anomaly disappears. Collectively, the results recommended that the predictive value of accruals and market participants' capability to process it were a significant driver of accrual-based anomalies.

\section{The proposed study}

This paper presents an empirical investigation to predict future cash flows using present cash flow and accruals using the information of 96 selected firms listed on Tehran Stock Exchange over the period 2007-2011. The proposed study uses linear regression techniques to forecast future cash flow based on both cash flow and discretionary accrual. In selection process, we consider the following criteria,

1. The shares of firms must be listed on Tehran Stock Exchange prior to year 2007.

2. All necessary information must be available during the time span.

3. The fiscal year must be March, 23, which is the official calendar in Iran.

4. No selected firm should have changed its fiscal calendar.

5. No holding firm is permitted for this study.

The proposed model of this paper considers different regression models. The first model considers the relationship between future cash flow $\left(\mathrm{CFO}_{i t+1}\right)$ as a function of present cash flow $\left(\mathrm{CFO}{ }_{i t}\right)$ as follows,

$C F O_{i t+1}=\gamma_{0}+\gamma_{1} \mathrm{CFO}_{i t}+\varepsilon_{i t}$

where $\gamma_{0}$ and $\gamma_{1}$ are coefficients to be estimated and $\varepsilon$ represents the residual. Future cash flow can be stated as a function of accruals $\left(A C C_{i t}\right)$ as follows,

$C F O_{i t+1}=\gamma_{0}+\gamma_{1} A C C_{i t}+\varepsilon_{i t}$

In addition, future cash flow can be stated as a function of both present cash flow and accruals as follows,

$$
C F O_{i t}=\gamma_{0}+\gamma_{1} C F O_{i t-1}+\gamma_{2} A C C_{i t-1}+\varepsilon_{i t}
$$

The other regression model investigates whether previous earnings $\left(E A R N_{i t-l}\right)$ could help present cash flow or not through the following regression model,

$C F O_{i t}=\mathcal{P}_{0}+\mathcal{P}_{1} E A R N_{i t-1}+\varepsilon_{i t}$

Similarly, in Eq. (4), $\mathcal{P}_{0}$ and $\mathcal{P}_{1}$ represent coefficients to be estimated and $\varepsilon$ is the residuals. Another hybrid model predicts cash flow through the following regression model,

$C F O_{i t}=\beta_{0}+\beta_{1} C F O_{i t-1}+\beta_{2} \Delta A R_{i t-1}+\beta_{3} \Delta I N N_{i t-1}+\beta_{4} \Delta A P_{i t-1}+\beta_{5} D E P A M O R_{i t-1}+\beta_{6}$ Other $_{i t-1}+\varepsilon_{i t,}$

where $\triangle A R_{i t-1}$ represents the change in working capital from the previous year, $\Delta I N N_{t-1}$ is the change in receivable accounts from the previous year, $\triangle A P{ }_{i t-1}$ represents changes on payable accounts, $D E P A M O R_{i t-1}$ states depreciation and amortization of the previous year and finally Other $_{i t-1}$ states the 
difference between $A C C$ and $\triangle A R+\triangle I N V$ - $\triangle A P-D E P A M O R$. In addition, $\beta_{i} \mathrm{i}=0, \ldots, 6$ represents coefficients to be estimated and $\varepsilon$ represents the residual. The proposed study considers the following regression model,

$A B S E_{1}-A B S E_{3}=\alpha_{0}+\beta_{1} A B S_{-} D i s C_{-} A C C+\beta_{2} A B S \_N O N D I S C \_A C C+\beta_{3} S I G N \_A C C+\beta_{4}$

$C F O \_$Volatility $+\beta_{5}$ Firm_Size $+\beta_{6}$ Book_to_Market $+\beta_{7}$ Audit $+\varepsilon_{i t}$

In Eq. (6), $A B S E_{j}$ represents the absolute deviation of cash flow, which is calculated as follows,

$$
A B S E_{j}=\frac{C F O_{t+1}-C F O_{t+1}^{*}}{\text { Assets }_{t}}
$$

In Eq. (7), $j$ represents the models presented in Eqs. (1-4), $A B S_{-} D i s c_{-} A C C$ and $A B S \_N O N D I S C \_A$ state the absolute value of discretionary and non-discretionary accruals, respectively. SIGN_ACC is a dummy variable, which is one if accrual predicts more future cash flow and zero, otherwise. In

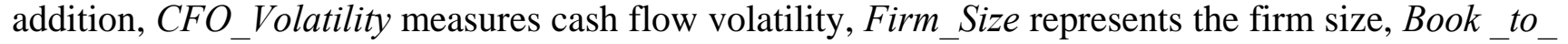
Market represents book value to market value, and finally Audit is dummy variable, which receives one if the firm is audited by a governmental auditing firm and zero, otherwise.

\section{The results}

In this section, we present details of our findings on testing the hypotheses of the survey.

\subsection{The first model}

We first compare the coefficient of determinations for the first and the second models, which are 0.149 and 0.375 , respectively. Therefore, we understand the second model provides better prediction power than the first model. In other words, accruals is a better predictor of future cash flow than present cash flow.

\subsection{The second model}

The second hypothesis of this survey investigates whether cash flow itself predicts better than cash flow and accruals together. Coefficient of determinations for the first and third models are calculated as $0.149,0.547$, respectively. Therefore, we state that the present cash flow and accruals together are able to provide better forecast for future cash flow.

Next, we present details of our findings on examining the effects of firms with various levels of accruals. In our study, we have decided to categorize the firms into four groups from the lowest degrees of accruals to the highest degrees of accruals. Table 1 demonstrates the results of some basic statistics of accruals on these four groups.

\section{Table 1}

The summary of some basic statistics on different levels of accruals

\begin{tabular}{lccccc}
\hline Return variable & Number & Mean & Standard deviation & Min & Max \\
\hline Group 1: The lowest level of accruals & 175 & 0.1576 & 0.679 & -0.74 & 7.34 \\
Group 2 & 175 & 0.2314 & 0.5757 & -0.57 & 4.52 \\
Group 3 & 185 & 0.2932 & 0.6194 & -0.59 & 4.78 \\
Group 4: The highest level of accruals & 180 & 0.3733 & 0.6256 & -0.70 & 3.86 \\
\hline
\end{tabular}

As we can observe from the results of Table 1, there are some meaningful difference between the means of the first and the last group. Performing Levin and one-way F tests on the data yields 1.886 with Sig. $=0.142$ and F-value $=3.806$ with Sig. $=0.010$. This means there are some meaningful 
differences between different groups. Table 2 shows the results of LSD tests between different groups.

Table 2

The summary of LSD test

\begin{tabular}{ccccc}
\hline Sub-group I & Sub-group J & Difference & Sig. & Result \\
\hline \multirow{2}{*}{ Group 1 } & 2 & -0.07378 & 0.271 & Meaningful \\
& 3 & -0.1356 & 0.04 & Not Meaningful \\
& 4 & -0.2156 & 0.001 & Meaningful \\
\hline \multirow{2}{*}{ Group 2 } & 1 & 0.0738 & 0.271 & Meaningful \\
& 3 & -0.06182 & 0.349 & Meaningful \\
\hline \multirow{2}{*}{ Group 3 } & 4 & -0.1418 & 0.033 & Not Meaningful \\
& 1 & 0.1356 & 0.006 & Not Meaningful \\
& 2 & 0.0618 & 0.249 & Meaningful \\
\hline \multirow{2}{*}{ Group 4 } & 4 & -0.080 & 0.222 & Meaningful \\
& 1 & 0.2156 & 0.001 & Meaningful \\
& 2 & 0.1418 & 0.033 & Not Meaningful \\
\hline
\end{tabular}

According to the results of Table 2, we can observe that the firms with higher accruals maintain lower return compared with firms with lower return. This means there is clear evidence of discretionary accruals on Tehran Stock Exchange.

\section{Conclusion}

In this paper, we have presented an empirical investigation on learning the effect of present cash flow as well as accruals on predicting future cash flow on selected firms on Tehran Stock Exchange. The proposed study has implemented various regression models for learning this effect and the results have indicated that cash flow and accruals together are better predictors of future cash flow than individual models, i.e. present cash flow or accruals. In addition, the study has concluded that the firms with higher accruals maintain lower return compared with firms with lower return.

\section{Acknowledgement}

The authors would like to thank the anonymous referees for constructive comments on earlier version of this paper.

\section{References}

Collins, D. W., \& Hribar, P. (2000). Earnings-based and accrual-based market anomalies: one effect or two?. Journal of Accounting and Economics, 29(1), 101-123.

Dechow, P., and Dichev, I. (2002). The quality of accruals and earnings: The role of accrual estimation error. Accounting Review, 77, 35-59.

Doyle, J. T., Lundholm, R. J., \& Soliman, M. T. (2003). The predictive value of expenses excluded from pro forma earnings. Review of Accounting Studies,8(2-3), 145-174.

Francis, J., LaFond, R., Olsson, P., \& Schipper, K. (2005). The market pricing of accruals quality. Journal of Accounting and Economics, 39(2), 295-327.

Hribar, P., \& Craig Nichols, D. (2007). The use of unsigned earnings quality measures in tests of earnings management. Journal of Accounting Research,45(5), 1017-1053.

Nam, S., Brochet, F., \& Ronen, J. (2012). The predictive value of accruals and consequences for market anomalies. Journal of Accounting, Auditing \& Finance, 27(2), 151-176.

Ohlson, J. (1995). Earnings, book values, and dividends in equity valuation. Contemporary Accounting Research, 11, 661-687. 